\title{
Reactivity of (3-Methylpentadienyl)iron(1+) Cation: Late-stage Introduction of a (3-Methyl-2Z,4-pentadien-1-yl) Side Chain
}

\author{
Subhabrata Chaudhury, Shukun Li, and William A. Donaldson* \\ Department of Chemistry, Marquette University, P. O. Box 1881, Milwaukee, WI 53201-1881 USA
}

\begin{abstract}
The 3-methyl-2Z,4-pentadien-1-yl sidechain is found in various sesquiterpenes and diterpenes. A route for the late stage introduction of this functionality was developed which relies on nucleophilic attack on the (3-methylpentadienyl)iron(1+) cation, followed by oxidative decomplexation. This methodology was applied to the synthesis of the proposed structure of heteroscyphic acid A methyl ester. Realization of this synthesis led to a correction of the proposed structure.
\end{abstract}

Keywords: Organoiron complexes; Alkylation; Diene ligands; Terpenoids

\section{Introduction}

The 3-methyl-2Z,4-pentadienyl sidechain is a functionality appearing in a number of naturally occurring sesquiterpenes and diterpenes. For example, (+)-striatene ${ }^{1}$ (1, Figure 1), and the labdane diterpenes (+)-solidagol ${ }^{2} \mathbf{2}$ and (-)-ent-3 $\beta$-acetoxylabda-8(17),12Z,14-trien-2 $\alpha$-ol ${ }^{3} \mathbf{3}$ were isolated from the liverwort Ptychanthus striatus, from Canadian golden rod (Solidago canadensis) and from the ornamental plant Plectranthus fruticosus respectively. Similarly, the clerodane diterpene (+)- caseargrewiin E $\mathbf{4}^{4}$, isolated from a Thai shrubby tree, exhibited cytotoxic activity against $\mathrm{KB}, \mathrm{BC} 1$ and NCI-H187 cancer cell lines in the range 0.15$0.91 \mu \mathrm{g} / \mathrm{mL}$ range. In spite of these and other examples ${ }^{5}$, only a single synthesis of a terpene containing this functionality has been reported ${ }^{6}$. Audran and co-workers reported the synthesis of 1 which involved enolate alkylation with 5Z-bromo-3-methylpent-3-en-1-yne, followed by hydrozirconation (Scheme 1). It should be noted that attempts at reduction of the $\mathbf{5}$ using $\mathrm{H}_{2}$ and a poisoned catalyst were unsuccessful.

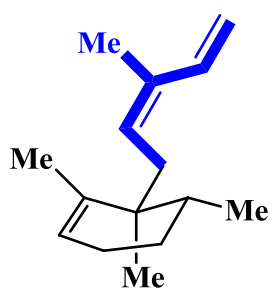

1

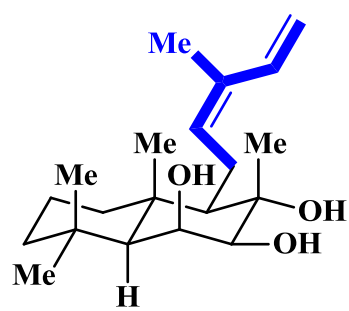

2

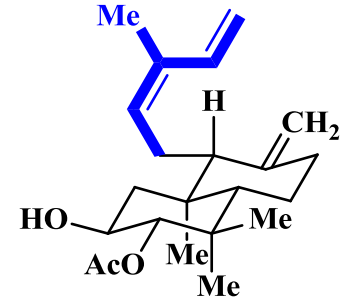

3

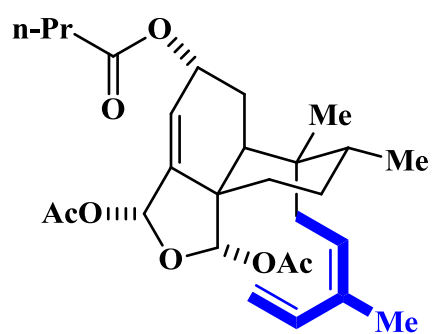

4

Figure 1. Sesquiterpenes and diterpenes possessing a 3-methyl-2Z,4-pentadienyl sidechain.

As part of our interest in the application of organoiron complexes to organic synthesis ${ }^{7}$, we have examined the reactivity the (3-methylpenta- dienyl) $\mathrm{Fe}(\mathrm{CO})_{2} \mathrm{PPh}_{3}{ }^{+}$cation (6, Scheme 2) with nucleophiles as a means for late-stage introduction of the 3-methyl-2Z,4-pentadienyl sidechain ${ }^{8}$. 


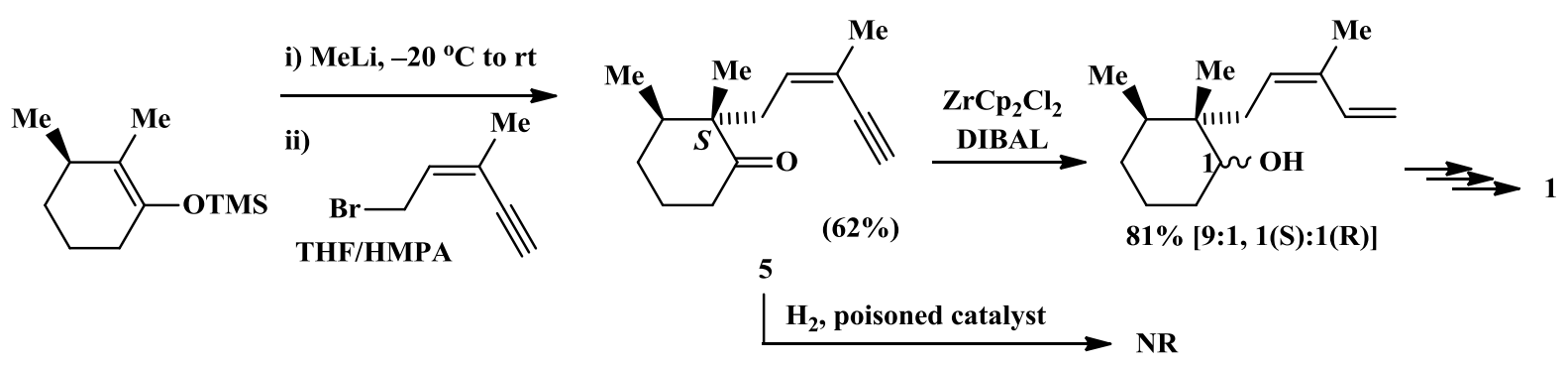

Scheme 1. Synthesis of the (3-methyl-2Z,4-pentadien-1-yl) side chain of (+)-striatene (ref. 5).

Heteroscyphic acids A, B and C, isolated from cultured cells of Heteroscyphus planus, were assigned the proposed structures $\mathbf{7 a}, \mathbf{7 b}$, and $\mathbf{7 c}$ (Figure 2) containing a 3-methyl-2Z,4-pentadienyl sidechain on the basis of their spectroscopic data ${ }^{9}$. We have previously $8 \mathrm{a}$ utilized the (3-methylpentadienyl) $\mathrm{Fe}^{+}$cation 6 to prepare the methyl ester of the 8-desmethyl-analog (8) of 7a. Comparison of the NMR spectral data for $\mathbf{8}$ with that reported for heteroscyphic acid $A$ led to the conclusion that the structures of the heteroscyphic acids were more consistent with a 3-methyl-2E, 4-pentadienyl sidechain. We herein report the full experimental details for these studies.

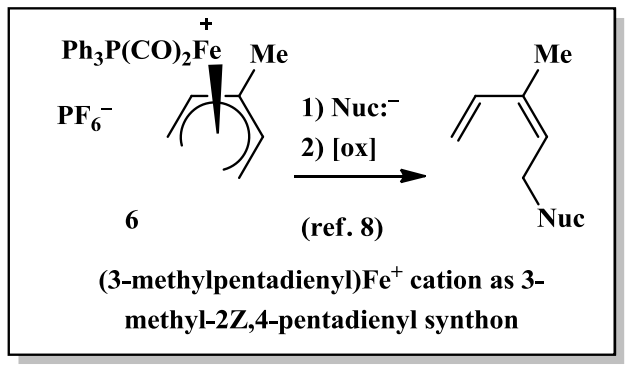

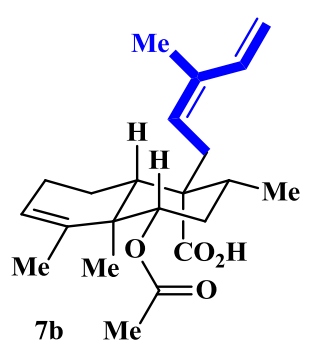

$7 \mathbf{a}, \mathbf{R}=\mathbf{H}, \mathbf{R}^{\prime}=\mathbf{M e}$ $\mathbf{8}, \mathbf{R}=\mathbf{M e}, \mathbf{R}^{\prime}=\mathbf{H}$

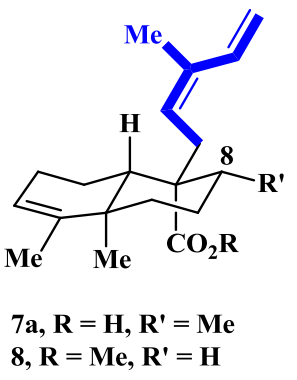

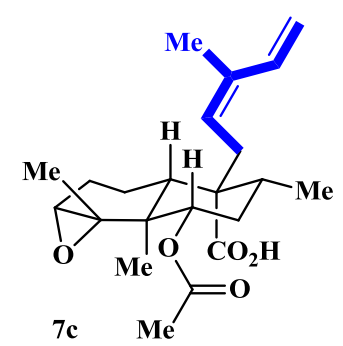

Figure 2. (3-Methylpentadienyl)Fe ${ }^{+}$cation as a synthon for 3-methyl-2Z,4-pentadien-1-yl and the "proposed" structures for heteroscyphic acids A, B and C.<smiles>C=CC1CCC=C(CBr)C1</smiles><smiles>C=CCCCCCCCC(C)=O</smiles>

10<smiles>COC(=O)C1CCC2C1CCCC2(C)C</smiles>

$( \pm)-16(66 \%)$

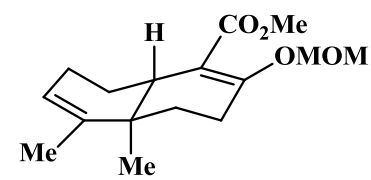

$( \pm)-15(64 \%)$ i) LDA

ii) MOMC

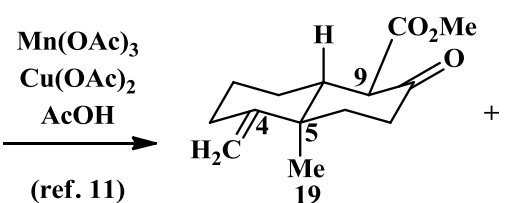

trans-11 (42-54\%) $\downarrow$ pTsOH $/ \mathrm{C}_{6} \mathrm{H}_{6} / \mathrm{D}$

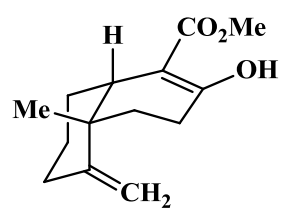

cis-12 (5-10\%)

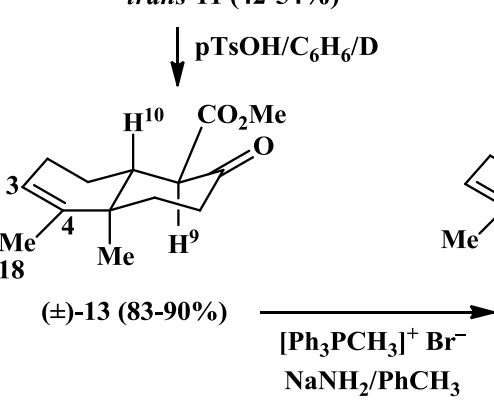

$$
\begin{array}{r}
\mathrm{Li} / \mathrm{NH}_{3} / \mathrm{THF} \\
\text { then } \mathrm{NH}_{4} \mathrm{Cl}
\end{array}
$$

Scheme 2. Synthesis of octahydronaphthalene synthons (heteroscyphic atom numbering).

\section{Results and Discussion}

Alkylation of the dianion of methylacetoacetate with the known ${ }^{10}$ bromide 9 gave the acyclic $\beta$ ketoester 10 (Scheme 2). Oxidative cyclization of 10, according to the literature procedure ${ }^{11}$ gave a chromatographically separable mixture of transdecalone $( \pm)-11$ along with minor amounts of the cisisomer $( \pm)$-12. Separation of these two isomers was facilitated by the fact that $\mathbf{1 2}$ exists almost entirely in its enol tautomer. Compounds $\mathbf{1 1}$ and $\mathbf{1 2}$ were characterized by comparison to the literature data for the corresponding ethyl esters ${ }^{11}$. Acid catalyzed 
isomerization of the exocyclic olefin of $\mathbf{1 1}$ gave the endocyclic isomer $( \pm)-\mathbf{1 3}$. The structural assignment of 13 was based on its NMR spectral data. In particular signals at $\delta 140.1$ and $122.2 \mathrm{ppm}$ in the ${ }^{13} \mathrm{C}$ NMR spectrum and at $\delta 5.29(1 \mathrm{H}, \mathrm{m})$ and $1.65 \mathrm{ppm}(3 \mathrm{H}, \mathrm{d}, J=1.5 \mathrm{~Hz})$ in the ${ }^{1} \mathrm{H}$ NMR spectrum are characteristic of the C-3 and C-4 olefinic carbons and their associated proton and methyl group respectively.

Attempted olefination of $\mathbf{1 3}$ with the ylide generated from the reaction of butyl lithium with methyltriphenylphosphonium bromide in THF gave recovered starting material; presumably due to deprotonation of the acidic $\beta$-ketoester in polar solvents. Alternatively, addition of the salt-free ylide generated from trimethylphosphonium bromide with sodium amide in toluene ${ }^{12}$ to $\mathbf{1 3}$ gave $( \pm)-\mathbf{1 4}$ in moderate yield. The structural assignment of $\mathbf{1 4}$ was based on its NMR spectral data. In particular, signals at $\delta 146.2$ and $107.9 \mathrm{ppm}$ in the ${ }^{13} \mathrm{C} \mathrm{NMR}$ spectrum and at $\delta 4.80(1 \mathrm{H}$, br s) and $4.49 \mathrm{ppm}(1 \mathrm{H}$, br s) in the ${ }^{1} \mathrm{H}$ NMR spectrum are characteristic of the exocyclic olefinic carbons and the attached protons.

$\beta$-Ketoester 13 was converted into its methoxymethyl vinyl ether $( \pm)-\mathbf{1 5}$ by treatment with LDA followed by reaction with $\mathrm{MOMCl}$. $O$-alkylation (as compared to $C$-alkylation) was evident by the presence of two olefinic peaks in the ${ }^{13} \mathrm{C}$ NMR spectrum of $\mathbf{1 5}$ at $\delta 151.1$ and $116.3 \mathrm{ppm}$. Treatment of $\mathbf{1 5}$ with $\mathrm{Li} / \mathrm{NH}_{3}$ gave $( \pm)-\mathbf{1 6}$ via reduction of the enoate of $\mathbf{1 5}$, followed by elimination of $\mathrm{CH}_{3} \mathrm{OCH}_{2} \mathrm{O}^{-}$anion and reduction of the resultant enoate ${ }^{13}$. The ester substituent in $\mathbf{1 6}$ was assigned to occupy an axial orientation on the basis of its ${ }^{1} \mathrm{H}$ NMR spectral data. In particular, the signal for H-9 ( $\delta$ 2.57-2.49 ppm) of $\mathbf{1 6}$ did not evidence any large couplings, and thus pointed to an equatorial orientation for H-9.

With octahydronaphthalene synthons 13,14 , and 16 successfully prepared, attention was turned to installation of the 3-methyl-2Z,4-pentadien-1-yl sidechain. Toward this end, the sodium salt of 13, generated by reaction with sodium hydride, was reacted with (3-methylpentadienyl)iron $(1+)$ cation 6 to afford a mixture of diastereomeric complexes 17/17' (Scheme 3). While the mixture of 17/17' gave a satisfactory combustion analysis, interpretation of the NMR spectra was complicated due to signal overlap of the diastereomers as well as ${ }^{31} \mathrm{P}$ coupling. Nonetheless, oxidative decomplexation of this mixture gave a single product $( \pm)-18$. In a similar fashion, the lithium salt of $\mathbf{1 4}$ or 16 (generated by reaction with LDA) with 6 , gave a mixture of isomeric complexes 19/19' or 20/20' respectively; decomplexation of each mixture gave a single product $( \pm)-\mathbf{2 1}$ or $( \pm)-\mathbf{8}$.

The structural assignments for 18, 21 and $\mathbf{8}$ were based on their NMR spectral data. For products $\mathbf{1 8}$ and 21, the pentadienyl sidechain was assigned the $\beta$-orientation, while for $\mathbf{8}$ the sidechain was assigned the $\alpha$-orientation. In particular, for $\mathbf{1 8}$ the singlet for Me-19 appears at $\delta 1.03 \mathrm{ppm}$ while for $\mathbf{8}$ this singlet appears at $\delta 0.84 \mathrm{ppm}$. The upfield chemical shift for this signal of $\mathbf{8}$ is consistent with an axial ester group at C-9 ${ }^{14}$. In addition, there is an $\mathrm{nOE}$ interaction observed between Me-19 and one of the $\mathrm{H}-12$ protons of $\mathbf{1 8}$, while a NOESY interaction was observed between the Me-19 and the methyl ester of 8. For 21 the upfield chemical shifts of the H-17 olefinic methylene protons ( $\delta 4.78$ and $5.00 \mathrm{ppm}$ ) may be attributed to the anisotropic effect of the neighboring ester substituent in an $\alpha$-orientation. Notably, these orientations are consistent with the known ${ }^{15}$ stereoselectivity for alkylation on the $\alpha$-face of other bicyclo[4.4.0]decane $\beta$-ketoesters while alkylation of the exocyclic enolate derived from a bicyclo[4.4.0]decane 2-carboxylate generally proceeds on the $\beta$-face ${ }^{16}$. In addition, the 3 -methyl2,4-pentadienyl side chain for 18, 21 and $\mathbf{8}$ were all assigned the $Z$-configuration. In particular, the signals for $\mathrm{H}-14$ appear at ca. $\delta$ 6.8-6.7 ppm while signals for the C-14, C-15 and the dienyl methyl C-16 appear at ca. $\delta 135,114$ and $20 \mathrm{ppm}$ respectively. These chemical shifts are characteristic of a 3-methyl-2Z,4-pentadienyl group ${ }^{2-5}$. This was found to be in sharp contrast to the chemical shifts reported ${ }^{9}$ for $\mathrm{H} 14$ ( $\left.\delta 6.37 \mathrm{ppm}\right) \mathrm{C} 14, \mathrm{C} 15$ and the dienyl methyl C16 ( $\delta 141.7,111.1$ and $12.1 \mathrm{ppm})$ of the sidechain of heteroscyphic acid methyl ester. In fact, these chemical shifts are more consistent with those reported ${ }^{17}$ for diterpenes which possess a 3-methyl-2E,4-pentadienyl sidechain. 


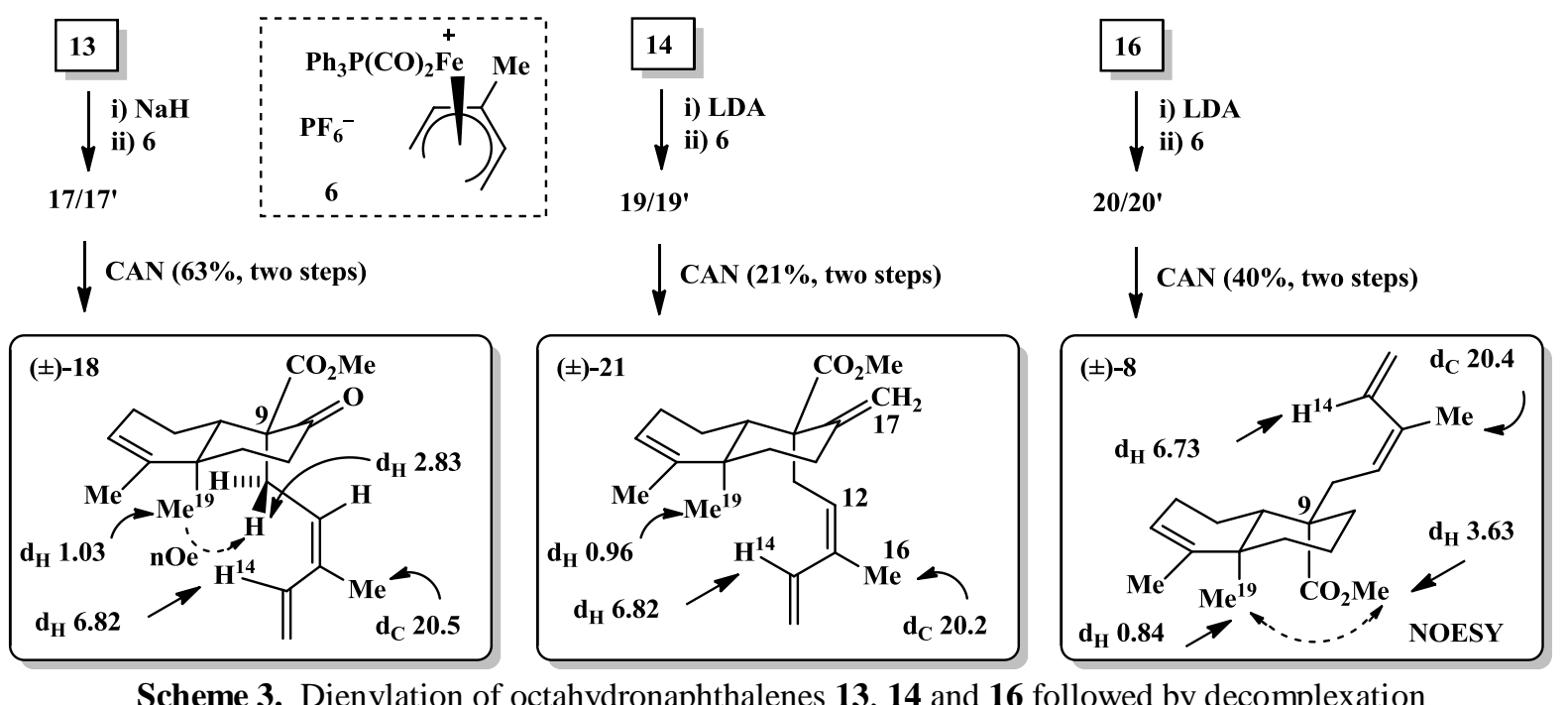

Scheme 3. Dienylation of octahydronaphthalenes 13, 14 and 16 followed by decomplexation (heteroscyphic acid atom numbering).

\section{Conclusion}

The ability to rapidly introduce a 3-methyl-2Z, 4-pentadienyl sidechain was demonstrated by the synthesis of $\mathbf{8}$, a nor-diterpene related to the proposed structure of heteroscyphic acid A, as well as $\mathbf{1 8}$ and 21. While this synthetic exercise revealed that the sidechains of the heteroscyphic acids more likely possess the E-stereochemistry, this methodology might be applied to the synthesis of compounds such as 1-4.

\section{Acknowledgements}

This work was supported by the National Science Foundation (CHE-0415771). Mass spectrometry was provided by the Washington University Mass Specrometry Resource, an NIH Research Resource.

\section{Experimental Section}

${ }^{1} \mathrm{H}$ and proton-decoupled ${ }^{13} \mathrm{C}$ NMR spectra were recorded at $300 \mathrm{MHz}$ and $75 \mathrm{MHz}$ respectively. Proton and carbon assignments refer to heteroscyphic acid skeleton numbering. Highresolution mass spectra were obtained from the Washington University Resource for Biomedical and Bioorganic mass spectrometry. Tetrahydrofuran was distilled from sodium benzophenone ketyl prior to use. Anhydrous $\mathrm{CH}_{2} \mathrm{Cl}_{2}$ and anhydrous DMF were purchased from Aldrich Chemical Company. Compounds $6^{8 \mathrm{~b}}$ and $9^{10}$ were prepared by literature procedures.

Methyl 6-methyl-3-oxo-6,11-dodecadienoate (10). To a flame-dried round-bottom flask, $\mathrm{NaH}$ (60\% dispersion in mineral oil, $2.53 \mathrm{~g}, 63.3 \mathrm{mmol}$ ) was suspended in dry THF $(165 \mathrm{~mL})$ under $\mathrm{N}_{2}$. The suspension was cooled in an ice bath and methyl acetoacetate $(6.81 \mathrm{~g}, 58.7 \mathrm{mmol})$ was added slowly
(CAUTION: hydrogen gas is evolved during the addition). The mixture was stirred for $10 \mathrm{~min}$, and then a solution of $n$-butyl lithium in THF $(2.5 \underline{\mathrm{M}}$, $25.3 \mathrm{~mL}, 63.3 \mathrm{mmol}$ ) was added. During this addition, the solution became a bright orange in color. After stirring at $0{ }^{\circ} \mathrm{C}$ for $10 \mathrm{~min}$, a solution of 1-bromo-2-methyl-2,7-octadiene (5.96 g, $29.4 \mathrm{mmol}$ ) in THF $(15 \mathrm{~mL})$ was added. The ice bath was removed and the solution stirred at room temperature for $30 \mathrm{~min}$. A solution of $3 \underline{\mathrm{M} \mathrm{HCl}}(50 \mathrm{~mL})$ was added followed by ether $(50 \mathrm{~mL})$. The mixture was separated and the aqueous layer was extracted several time with ether. The combined organic layers were dried $\left(\mathrm{MgSO}_{4}\right)$ and concentrated under reduced pressure. The residue was purified by column chromatography $\left(\mathrm{SiO}_{2}\right.$, hexanes-ethylacetate $=8: 1 \rightarrow 5: 1$ gradient) to afford $\mathbf{1 0}$

$(5.21 \mathrm{~g}, 75 \%)$ as a pale yellow oil;

IR (neat) 3076, 2927, 1750, 1717, 1637, $911 \mathrm{~cm}^{-1}$.

${ }^{1} \mathbf{H}$ NMR $\left(\mathrm{CDCl}_{3}\right): \delta=5.80(1 \mathrm{H}, \mathrm{dtd}, J=16.9,6.8$, $3.3 \mathrm{~Hz}, \mathrm{H}-11), 5.13$ (1H, br t, $J=7.7 \mathrm{~Hz}, \mathrm{H}-7), 4.97$ $\left(2 \mathrm{H}, \mathrm{m},=\mathrm{CH}_{2}\right), 3.74(3 \mathrm{H}, \mathrm{s}, \mathrm{OMe}), 3.46(2 \mathrm{H}, \mathrm{s}, \mathrm{H}-2)$, $2.64(2 \mathrm{H}$, br t, $J=7.5 \mathrm{~Hz}), 2.27(2 \mathrm{H}$, br t, $J=7.8$ $\mathrm{Hz}), 2.04-1.78$ (4H, m), 1.59 (3H, s, Me-6), 1.41 (2H, pent, $J=7.3 \mathrm{~Hz}$ ).

${ }^{13} \mathrm{C}$ NMR $\left(\mathrm{CDCl}_{3}\right): \delta=202.5(\mathrm{C}-3), 167.7(\mathrm{C}-1)$, 138.9 (C-10), 133.3 (C-6), 125.4 (C-7), 114.6 (C-11), 52.6 (OMe), 49.2, 42.0, 33.6, 33.4, 29.2, 27.6, 16.4 (Me-6).

Anal. Calcd for $\mathrm{C}_{14} \mathrm{H}_{22} \mathrm{O}_{3}: \mathrm{C}, 70.56 ; \mathrm{H}, 9.30$. Found: C, $70.65 ; \mathrm{H}, 9.17$.

Decahydro-4a-methyl-5-methylene-2-oxo-1naphthalenecarboxylic acid methyl ester (11). To a degassed solution of $\mathbf{1 0}(3.31 \mathrm{~g}, 13.9 \mathrm{mmol})$ dissolved in glacial acetic acid $(35 \mathrm{~mL})$ was added solid $\mathrm{Mn}(\mathrm{OAc})_{3}(1.75 \mathrm{~g}, 6.53 \mathrm{mmol})$, followed by solid $\mathrm{Cu}(\mathrm{OAc})_{2}(0.590 \mathrm{~g}, 3.24 \mathrm{mmol})$. The reaction mixture was stirred under $\mathrm{N}_{2}$ for $7 \mathrm{~h}$ at room temperature and then filtered through a bed of celite. The filter bed was washed several times with ether, 
the combined ethereal extracts were washed with saturated $\mathrm{NaHCO}_{3}$, followed by water, dried $\left(\mathrm{MgSO}_{4}\right)$ and concentrated under reduced pressure. The residue was purified by column chromatography $\left(\mathrm{SiO}_{2}\right.$, hexanes-ethyl acetate $=8: 1 \rightarrow 5: 1$ gradient $)$ to afford $( \pm)-\mathbf{1 1}$

(1.45 $\mathrm{g}, 44 \%)$ as a colorless oil, followed by a variable but minor amount of the cis-isomer (10).

11: IR (neat) 3086, 1715, $1635 \mathrm{~cm}^{-1}$.

${ }^{1} \mathbf{H}$ NMR $\left(\mathrm{CDCl}_{3}\right): \delta=4.74\left(1 \mathrm{H}\right.$, br s, $\left.=\mathrm{CH}_{2}\right), 4.65$ $\left(1 \mathrm{H}\right.$, br s, $\left.=\mathrm{CH}_{2}\right), 3.75(3 \mathrm{H}, \mathrm{s}, \mathrm{OMe}), 3.27(1 \mathrm{H}, \mathrm{d}$, $J=12.9 \mathrm{~Hz}, \mathrm{H}-9), 2.55-2.47$ (2H, m), 2.40-2.32 $(1 \mathrm{H}, \mathrm{m}), 2.05-1.76(6 \mathrm{H}, \mathrm{m}), 1.45-1.37(2 \mathrm{H}, \mathrm{m}), 1.22$ (3H, s, Me-19).

${ }^{13} \mathrm{C} \mathrm{NMR}\left(\mathrm{CDCl}_{3}\right): \delta=205.6(\mathrm{C}-8), 170.3\left(\mathrm{CO}_{2} \mathrm{R}\right)$, 155.0 (C-4), $106.3\left(=\mathrm{CH}_{2}\right), 60.3(\mathrm{C}-9), 52.3(\mathrm{OMe})$, 47.7, 38.1, 38.0, 36.1, 32.7, 27.6, 27.4, 17.5 (Me-19). FAB-HRMS $m / z \quad 237.1485$ (calcd for $\mathrm{C}_{14} \mathrm{H}_{21} \mathrm{O}_{3}$ $\left.\left[\mathrm{M}+\mathrm{H}^{+}\right] \mathrm{m} / z, 237.1491\right)$.

\section{1,2,3,4,4a,7,8,8a-Octahydro-4a,5-dimethyl-2-oxo-} 1-naphthalenecarboxylic acid methyl ester (13). To a solution of 11 (200 $\mathrm{mg}, 0.847 \mathrm{mmol})$ in benzene $(10 \mathrm{~mL})$ was added $p$-toluenesulfonic acid monohydrate $(30 \mathrm{mg}, 0.16 \mathrm{mmol})$. The mixture was heated at reflux for $2 \mathrm{~d}$ under $\mathrm{N}_{2}$. The mixture was cooled to room temperature and then a few drops of triethylamine were added to neutralize the acid. The mixture was filtered through a pad of celite, the filter bed washed with ether, and the combined organic layers were concentrated under reduced pressure. The residue was purified by column chromatography $\left(\mathrm{SiO}_{2}\right.$, hexanes-ethyl acetate $\left.=8: 1\right)$ to afford $( \pm)-\mathbf{1 3}$ (708 mg, 84\%) as a colorless oil; IR (neat) $1746,1712 \mathrm{~cm}^{-1}$.

${ }^{1} \mathbf{H}$ NMR $\left(\mathrm{CDCl}_{3}\right): \delta=5.29(1 \mathrm{H}$, br s, H-3), 3.74 (3H, s, OMe), 3.29 (1H, d, $J=13.5 \mathrm{~Hz}, \mathrm{H}-9), 2.50$ $2.42(2 \mathrm{H}, \mathrm{m}), 2.19$ (1H, td, $J=13.2,2.7 \mathrm{~Hz}, \mathrm{H}-10)$, 2.10-1.97 (3H, m), 1.65 (3H, d, $J=1.5 \mathrm{~Hz}, \mathrm{Me}-18)$, 1.60-1.30 (3H, m), 1.16 (3H, s, Me-19).

${ }^{13} \mathrm{C}$ NMR $\left(\mathrm{CDCl}_{3}\right): \delta=206.0(\mathrm{C}-8), 170.5\left(\mathrm{CO}_{2} \mathrm{R}\right)$, 140.1 (C-4), 122.2 (C-3), 60.0 (C-9), 52.2 (OMe), 45.2, 37.9, 36.4, 35.3, 25.7, 23.8, 18.8 (Me-18), 17.7 (Me-19).

FAB-HRMS $m / z \quad 237.1485$ (calcd for $\mathrm{C}_{14} \mathrm{H}_{21} \mathrm{O}_{3}$ $\left.\left[\mathrm{M}+\mathrm{H}^{+}\right] \mathrm{m} / \mathrm{z} 237.1491\right)$.

\section{1,2,3,4,4a,7,8,8a-Octahydro-4a,5-dimethyl-2-} methylene-1-naphthalenecarboxylic acid methyl ester (14). To a suspension of $\mathrm{NaNH}_{2}(637 \mathrm{mg}, 16.3$ mmol) in dry toluene $(41 \mathrm{~mL})$ under $\mathrm{N}_{2}$, was added methyltriphenylphosphonium bromide (4.48 g, 12.5 $\mathrm{mmol})$, and the mixture was heated at reflux for $3 \mathrm{~h}$. During this time formation of the ylide was detected by change of the solution to a bright orange color. The warm solution was transferred by a cannula to a solution of $13(593 \mathrm{mg}, 2.51 \mathrm{mmol})$ in toluene (6 $\mathrm{mL}$ ) under $\mathrm{N}_{2}$. The reaction mixture was stirred at room temperature for $6 \mathrm{~h}$ and then filtered through a pad of celite. The filtrate was concentrated under reduced pressure and the residue was dissolved in hexanes to induce the precipitation of triphenylphosphine oxide and then filtered again. The filtrate was washed with water, dried $\left(\mathrm{MgSO}_{4}\right)$ and concentrated. The residue was purified by column chromatography $\left(\mathrm{SiO}_{2}\right.$, hexanes-ethyl acetate $=8: 1)$ to afford $( \pm)-\mathbf{1 4}$

(382 $\mathrm{mg}, 66 \%$ ) as a colorless oil.

IR (neat) 2937, 1740, 1645, $891 \mathrm{~cm}^{-1}$.

${ }^{1} \mathbf{H}$ NMR $\left(\mathrm{CDCl}_{3}\right): \delta=5.27-5.22(1 \mathrm{H}$, narrow $\mathrm{m}, \mathrm{H}-$ 3), $4.80\left(1 \mathrm{H}\right.$, br s, $\left.=\mathrm{CH}_{2}\right), 4.49\left(1 \mathrm{H}\right.$, br s, $\left.=\mathrm{CH}_{2}\right), 3.75$ (3H, s, OMe), $3.09(1 \mathrm{H}, \mathrm{d}, J=12.5 \mathrm{~Hz}, \mathrm{H}-9), 2.36-$ $2.29(2 \mathrm{H}, \mathrm{m}), 2.10-1.96(2 \mathrm{H}, \mathrm{m}), 1.82(1 \mathrm{H}, \mathrm{td}$, $J=12.3,3.1 \mathrm{~Hz}, \mathrm{H}-10), 1.62(3 \mathrm{H}$, br s, Me-18), 1.55-1.20 (4H, m), 1.06 (3H, s, Me-19).

${ }^{13} \mathrm{C} \mathrm{NMR}\left(\mathrm{CDCl}_{3}\right): \delta=174.1\left(\mathrm{CO}_{2} \mathrm{R}\right), 146.2(\mathrm{C}-8)$, 141.7 (C-4), $121.1(\mathrm{C}-3), 107.9\left(=\mathrm{CH}_{2}\right), 52.0(\mathrm{OMe})$, 51.6, 45.7, 37.0, 36.7, 31.4, 25.9, 23.2, 18.8, 18.2.

FAB-HRMS $m / z \quad 234.1615$ (calcd for $\mathrm{C}_{15} \mathrm{H}_{22} \mathrm{O}_{3}$ $\left[\mathrm{M}^{+}\right] \mathrm{m} / \mathrm{z}$ 234.1620).

\section{3,4,4a,7,8,8a-Hexahydro-2-(methoxymethoxy)-}

4a,5-dimethyl-1-naphthalenecarboxylic acid methyl ester (15). To a suspension of $\mathrm{NaH}(40 \mathrm{mg}$, $1.0 \mathrm{mmol})$ in HMPA $(3 \mathrm{~mL})$ at $0{ }^{\circ} \mathrm{C}$ under $\mathrm{N}_{2}$ was added a solution of $\mathbf{1 3}(200 \mathrm{mg}, 0.847 \mathrm{mmol})$ in HMPA ( $3 \mathrm{~mL})$. The reaction mixture was warmed to room temperature over a $2 \mathrm{~h}$ period. To this solution was added chloromethyl methyl ether $(82 \mathrm{mg}, 1.0$ mmol) and the reaction mixture was stirred for an additional $3 \mathrm{~h}$. The resulting mixture was poured into a separatory funnel containing ice-water, saturated $\mathrm{NaHCO}_{3}(10 \mathrm{~mL})$ and ether $(15 \mathrm{~mL})$. The layers were separated, and the aqueous layer was extracted several times with ether. The combined organic layers were dried $\left(\mathrm{MgSO}_{4}\right)$ and concentrated under reduced pressure. The residue was purified by column chromatography $\left(\mathrm{SiO}_{2}\right.$, hexanes-ethyl acetate $=10: 1)$ to afford $( \pm)-\mathbf{1 5}$

(150 mg, 64\%) as a colorless solid; $\mathrm{mp} 65-68^{\circ} \mathrm{C}$;

IR (neat) 2949, 2830,1725, $1680 \mathrm{~cm}^{-1}$.

${ }^{1} \mathbf{H}$ NMR $\left(\mathrm{CDCl}_{3}\right): \delta=5.23(1 \mathrm{H}$, br s, H-3), 4.91 $\left(1 \mathrm{H}, \mathrm{d}, J=6.9 \mathrm{~Hz}, \mathrm{OCH}_{2} \mathrm{OMe}\right), 4.85(1 \mathrm{H}, \mathrm{d}, J=6.9$ $\left.\mathrm{Hz}, \mathrm{OCH}_{2} \mathrm{OMe}\right), 3.73\left(3 \mathrm{H}, \mathrm{s}, \mathrm{CO}_{2} \mathrm{Me}\right), 3.42(3 \mathrm{H}, \mathrm{s}$, $\left.\mathrm{OCH}_{2} \mathrm{OMe}\right), 2.57-2.49$ (1H, m), 2.39-2.30 (2H, m), 2.10-2.02 (2H, m), 1.97-1.88 (1H, m), $1.64(3 \mathrm{H}, \mathrm{br} \mathrm{s}$, Me-18), 1.56-1.40 (3H, m), 0.98 (3H, s, Me-19).

${ }^{13} \mathrm{C}$ NMR $\left(\mathrm{CDCl}_{3}\right): \delta=169.5\left(\mathrm{CO}_{2} \mathrm{R}\right), 151.1(\mathrm{C}-8)$, 141.4 (C-4), 121.2 (C-3), 116.3 (C-9), 93.2 $\left(\mathrm{OCH}_{2} \mathrm{OMe}\right), 56.5\left(\mathrm{OCH}_{2} \mathrm{OMe}\right), 51.6\left(\mathrm{CO}_{2} \underline{\mathrm{Me}}\right)$, 41.7, 35.9, 31.8, 25.7, 22.8, 21.4, 18.9, 18.2.

Anal. Calcd for $\mathrm{C}_{16} \mathrm{H}_{24} \mathrm{O}_{4}: \mathrm{C}, 68.55 ; \mathrm{H}, 8.63$. Found: C, 68.69; H, 8.46.

\section{1,2,3,4,4a,7,8,8a-Octahydro-4a,5-dimethyl-1-} naphthalenecarboxylic acid methyl ester (16). To a dispersion of lithium metal $(80 \mathrm{mg}, 12 \mathrm{mmol})$ in liquid $\mathrm{NH}_{3}$ at $-78{ }^{\circ} \mathrm{C}$ under $\mathrm{N}_{2}$ was added a solution of $15(460 \mathrm{mg}, 1.64 \mathrm{mmol})$ in ether $(8 \mathrm{~mL})$. The reaction mixture was stirred at $-78{ }^{\circ} \mathrm{C}$ for $15 \mathrm{~min}$, and then quenched by addition of solid $\mathrm{NH}_{4} \mathrm{Cl}$ $(2.46 \mathrm{~g})$ in one portion. The mixture was stirred for 
an additional $30 \mathrm{~min}$ at $-78{ }^{\circ} \mathrm{C}$ and then slowly warmed to room temperature. Additional ether (30 $\mathrm{mL}$ ) was added, and the mixture was filtered through a pad of filter-aid. The inorganic salts were washed several times with ether and the combined ethereal layers were concentrated under reduced pressure. The residue was purified by column chromatography $\left(\mathrm{SiO}_{2}\right.$, hexanes-ethyl acetate $\left.=10: 1\right)$ to afford $( \pm)-\mathbf{1 6}$ (240 $\mathrm{mg}, 66 \%)$ as a colorless oil.

IR (neat) $1728 \mathrm{~cm}^{-1}$.

${ }^{1} \mathbf{H}$ NMR $\left(\mathrm{CDCl}_{3}\right): \delta=5.23(1 \mathrm{H}, \mathrm{m}, \mathrm{H}-3), 3.66(3 \mathrm{H}$, $\mathrm{s}, \mathrm{OMe}), 2.53(1 \mathrm{H}$, br t, $J=4.8 \mathrm{~Hz}, \mathrm{H}-9), 2.21-2.12$ $(1 \mathrm{H}, \mathrm{m}), 2.06-1.85(4 \mathrm{H}, \mathrm{m}), 1.80-1.72(2 \mathrm{H}, \mathrm{m}), 1.66-$ $1.61(1 \mathrm{H}, \mathrm{m}), 1.57(3 \mathrm{H}, \mathrm{d}, J=1.8 \mathrm{~Hz}, \mathrm{Me}-18), 1.44-$ $1.30(2 \mathrm{H}, \mathrm{m}), 1.13(1 \mathrm{H}, \mathrm{dt}, J=13.2,4.1 \mathrm{~Hz}), 0.86$ (3H, s, Me-19);

${ }^{13} \mathrm{C}$ NMR $\left(\mathrm{CDCl}_{3}\right): \delta=176.2\left(\mathrm{CO}_{2} \mathrm{R}\right), 143.0(\mathrm{C}-4)$, 121.2 (C-3), 51.3 (OMe), 46.1, 43.3, 38.3, 36.8, 28.6, 27.0, 25.5, 19.3, 18.2, 17.5.

EI-HRMS $m / z \quad 222.1619$ (calcd for $\mathrm{C}_{14} \mathrm{H}_{23} \mathrm{O}_{2}$ $\left[\mathrm{M}+\mathrm{H}^{+}\right] m / z$ 222.1620).

\section{1,2,3,4,4a,7,8,8a-Octahydro-4a,5-dimethyl-1-(3- methyl-2Z,4-pentadien-1-yl)-2-oxo-1-}

naphthalenecarboxylic acid methyl ester (18). To a solution of $\mathrm{NaH}(25 \mathrm{mg}, 0.64 \mathrm{mmol})$ in dry THF $(10 \mathrm{~mL})$ at $0{ }^{\circ} \mathrm{C}$ under $\mathrm{N}_{2}$, was added a solution of $\mathbf{1 3}$ $(150 \mathrm{mg}, 0.635 \mathrm{mmol})$ in THF $(10 \mathrm{~mL})$. The mixture was stirred for $30 \mathrm{~min}$, and then solid cation 6 (381 mg, $0.635 \mathrm{mmol}$ ) was added in one portion. The reaction mixture was stirred at $0{ }^{\circ} \mathrm{C}$ for $1 \mathrm{~h}$ and then $30 \mathrm{~min}$ at room temperature. The reaction mixture was poured into saturated $\mathrm{NaCl}$ solution $(15 \mathrm{~mL})$, and extracted several times with ethyl acetate. The combined extracts were dried $\left(\mathrm{MgSO}_{4}\right)$ and concentrated under reduced pressure. The residue was purified by column chromatography $\left(\mathrm{SiO}_{2}\right.$, hexanes-ethyl acetate $\left.=8: 1\right)$ to afford a mixture of diastereomeric diene-iron complexes 17/17'

(325 $\mathrm{mg}, 75 \%)$ as a yellow solid. $\mathrm{mp}$ (decomposes) $89-100{ }^{\circ} \mathrm{C}$

The ${ }^{1} \mathrm{H}$ and ${ }^{13} \mathrm{C}$ NMR spectra for this product were too complex for complete interpretation due to the presence of diastereomers.

${ }^{1} \mathbf{H}$ NMR (partial, $\left.\mathrm{CDCl}_{3}\right): \delta=7.56-7.30(\mathrm{~m}, 15 \mathrm{H}$, $\mathrm{PPh}_{3}$ ), 5.32-5.26 (m, 1H), 4.24-4.07 (br m, 1H), 3.63 and $3.61(2 \times$ s, $3 \mathrm{H})$.

Anal. calcd. for $\mathrm{C}_{40} \mathrm{H}_{43} \mathrm{O}_{5} \mathrm{PFe}$ : C, 69.57; H, 6.27. Found: C, 69.42; H, 6.40 .

To a solution of the $17 / 17^{\prime}(110 \mathrm{mg}, 0.159 \mathrm{mmol})$ in methanol $(10 \mathrm{~mL})$ was added solid ceric ammonium nitrate [CAN] $(220 \mathrm{mg}, 0.401 \mathrm{mmol})$ in two portions. Monitoring of the reaction by TLC indicated that complete disappearance of 17/17' in $30 \mathrm{~min}$. Water $(15 \mathrm{~mL})$ was added and the reaction mixture was extracted several times with ether. The combined organic extracts were dried $\left(\mathrm{MgSO}_{4}\right)$ and concentrated under reduced pressure. The residue was purified by column chromatography $\left(\mathrm{SiO}_{2}\right.$, hexanes-ethyl acetate $=10: 1)$ to afford $( \pm)-\mathbf{1 8}$
(50 mg, 99\%) as a colorless oil;

IR (neat) 2950, 1713, 1435, $1217 \mathrm{~cm}^{-1}$.

${ }^{1} \mathbf{H}$ NMR $\left(\mathrm{CDCl}_{3}\right): \delta=6.82(1 \mathrm{H}, \mathrm{dd}, J=17.3,10.7$ $\mathrm{Hz}, \mathrm{H}-14$ ), 5.30-5.18 (3H total, br $\mathrm{m} \& \mathrm{~d}, J=16.6$ $\mathrm{Hz}, \mathrm{H}-3, \mathrm{H} 12$ and $\left.\mathrm{H}-15_{Z}\right), 5.12(1 \mathrm{H}, \mathrm{d}, J=10.9 \mathrm{~Hz}$, $\left.\mathrm{H}-15_{E}\right), 3.66(3 \mathrm{H}, \mathrm{s}, \mathrm{OMe}), 2.83(1 \mathrm{H}, \mathrm{dd}, J=14.7$, $6.5 \mathrm{~Hz}, \mathrm{H}-11), 2.62(1 \mathrm{H}, \mathrm{dd}, J=14.4,9.1 \mathrm{~Hz}$, H-11'), 2.47 (1H, ddd, $J=15.5,4.7,2.3 \mathrm{~Hz}, \mathrm{H}-7_{\mathrm{eq}}$ ), 2.10-1.96 (1H, m), 1.90-1.78 (2H, m), $1.72(3 \mathrm{H}, \mathrm{s}$, Me-16), 1.65-1.63 (1H, m), 1.54 (3H, s, Me-18), $1.43(1 \mathrm{H}, \mathrm{td}, J=16.5,4.9 \mathrm{~Hz}), 1.08-1.04(2 \mathrm{H}, \mathrm{m})$, 1.03 (3H, s, Me-19).

${ }^{13} \mathrm{C} \mathrm{NMR}\left(\mathrm{CDCl}_{3}\right): \delta=208.0(\mathrm{C}-8), 173.9\left(\mathrm{CO}_{2} \mathrm{Me}\right)$, 141.2 (C-4), 135.1 (C-14), 133.3, 125.1, 122.4 (C-3), 114.6 (C-15), 61.8 (C-9), 52.3 (OMe), 50.0, 38.1, 37.7, 36.4, 31.0, 27.2, 21.1, 20.5 (Me-16), 18.6, 17.5. FAB-HRMS $m / z, 323.2182$ (calcd for $\mathrm{C}_{20} \mathrm{H}_{28} \mathrm{O}_{3} \mathrm{Li}$ $\left(\mathrm{M}+\mathrm{Li}^{+}\right) \mathrm{m} / z$ 323.2199).

\section{1,2,3,4,4a,7,8,8a-Octahydro-4a,5-dimethyl-1-(3- methyl-2Z,4-pentadien-1-yl)-2-methylene-1-} naphthalenecarboxylic acid methyl ester (21). To a solution of $14(100 \mathrm{mg}, 0.427 \mathrm{mmol})$ in dry THF $(10 \mathrm{~mL})$ at $0{ }^{\circ} \mathrm{C}$ under $\mathrm{N}_{2}$, was added a solution of lithium diisopropylamine in THF $(1.8 \underline{\mathrm{M}}, 0.3 \mathrm{~mL}$, $0.5 \mathrm{mmol})$. The mixture was stirred for $1 \mathrm{~h}$ at $0{ }^{\circ} \mathrm{C}$, and then solid cation $6(0.31 \mathrm{~g}, 0.54 \mathrm{mmol})$ was added in one portion. The reaction mixture was stirred for $3 \mathrm{~h}$ and then worked up in a fashion similar to that for 17/17'. Purification of the residue by column chromatography $\left(\mathrm{SiO}_{2}\right.$, hexanes-ethyl acetate $=20: 1$ ) gave a diastereomeric mixture of diene-iron complexes 19/19'

(70 mg, 30\%) as a yellow oil.

The ${ }^{1} \mathrm{H}$ and ${ }^{13} \mathrm{C}$ NMR spectra for this product were too complex for complete interpretation due to the presence of diastereomers.

${ }^{1} \mathbf{H}$ NMR (partial, $\left.\mathrm{CDCl}_{3}\right): \delta=7.56-7.32(\mathrm{~m}, 15 \mathrm{H}$, $\mathrm{PPh}_{3}$ ), 5.26-5.05 (m, 3H), 4.21-4.10 (br m, 1H), 3.64 and $3.61(2 \times \mathrm{s}, 3 \mathrm{H})$.

${ }^{13} \mathbf{C}$ NMR (partial, $\mathrm{CDCl}_{3}$, diastereomeric signals reported as pairs: $\delta=176.6$ and $175.8\left(\mathrm{CO}_{2} \mathrm{Me}\right)$, 149.7, 146.9, 142.9 and $142.6(\mathrm{C} 3), 136.3\left(\mathrm{~d}, J_{\mathrm{PH}}=\right.$ $37.5 \mathrm{~Hz}), 133.3\left(\mathrm{~d}, J_{\mathrm{PH}}=10.2 \mathrm{~Hz}\right), 129.8,128.3$ $\left(\mathrm{d}, J_{\mathrm{PH}}=8.7 \mathrm{~Hz}\right), 121.7$ and 121.2, 112.0 and 111.1, 103.1 and 102.3, 94.1 and 93.45.

Anal. calcd. for $\mathrm{C}_{41} \mathrm{H}_{45} \mathrm{O}_{4} \mathrm{PFe} \cdot \mathrm{H}_{2} \mathrm{O}$ : C, 69.70; H, 6.70. Found: C, 69.77; H, 6.95.

Decomplexation of the mixture of 19/19' (70 mg, $0.16 \mathrm{mmol})$ in methanol $(10 \mathrm{~mL})$ with CAN (112 mg, $0.204 \mathrm{mmol}$ ) was carried out in a fashion similar to the decomplexation of 17/17'. Purification of the residue by column chromatography $\left(\mathrm{SiO}_{2}\right.$, hexanes-ethyl acetate $=10: 1$ ) gave $( \pm)-21$

(22 $\mathrm{mg}, 70 \%$ ) as a colorless oil;

IR (neat) 2963, 1718, 1436, $1265 \mathrm{~cm}^{-1}$.

${ }^{1} \mathbf{H}$ NMR $\left(\mathrm{CDCl}_{3}\right): \delta=6.82(1 \mathrm{H}, \mathrm{dd}, J=17.4,10.9$ $\mathrm{Hz}, \mathrm{H}-14), 5.34$ (1H, t, $J=6.5 \mathrm{~Hz}, \mathrm{H}-12), 5.28-5.20$ $\left(2 \mathrm{H}, \mathrm{m}, \mathrm{H}-3\right.$ and $\left.\mathrm{H}-15_{\mathrm{Z}}\right), 5.13(1 \mathrm{H}, \mathrm{d}, J=10.6 \mathrm{~Hz}$, $\left.\mathrm{H}-15_{E}\right), 5.00\left(1 \mathrm{H}, \mathrm{s}, \mathrm{H}-17_{E}\right), 4.78\left(1 \mathrm{H}, \mathrm{s}, \mathrm{H}-17_{Z}\right)$, 
$3.65(3 \mathrm{H}, \mathrm{s}, \mathrm{OMe}), 2.86-2.63(3 \mathrm{H}, \mathrm{m}), 2.34-2.25$ $(1 \mathrm{H}, \mathrm{m}), 2.02-1.78(8 \mathrm{H}, \mathrm{m}), 1.57(3 \mathrm{H}$, br s, Me-18), 1.30-1.20 (2H, m), 0.95 (3H, s, Me-19).

${ }^{13} \mathrm{C}$ NMR $\left(\mathrm{CDCl}_{3}\right): \delta=176.4\left(\mathrm{CO}_{2} \mathrm{R}\right), 148.8(\mathrm{C}-8)$, 142.7 (C-4), 133.9, 133.7, 125.6, 121.7 (C-3), 114.5 (C-15), 110.6 (C-17), 53.7, 50.6, 38.9, 38.4, 32.4, 31.6, 29.9, 27.5, 20.8, 20.2 (Me-16), 18.4, 17.8.

FAB-HRMS $m / z \quad 314.2240$ (calcd for $\mathrm{C}_{21} \mathrm{H}_{30} \mathrm{O}_{2}$ $\left[\mathrm{M}+\mathrm{H}^{+}\right] \mathrm{m} / \mathrm{z}$ 314.2246).

\section{1,2,3,4,4a,7,8,8a-Octahydro-4a,5-dimethyl-1-(3- methyl-2Z,4-pentadienyl)-1-}

naphthalenecarboxylic acid methyl ester (8). To a solution of $16(100 \mathrm{mg}, 0.451 \mathrm{mmol})$ in dry THF (4 mL) at $-78{ }^{\circ} \mathrm{C}$ under $\mathrm{N}_{2}$, was added a solution of lithium diisopropylamine in THF $(0.5 \mathrm{mmol}$, freshly prepared from diisopropylamine and $n$-butyl lithium). The mixture was stirred for $30 \mathrm{~min}$, and then solid cation 6 (207 mg, $0.451 \mathrm{mmol}$ ) was added in one portion. The reaction mixture was warmed at room temperature and stirred for an additional $3 \mathrm{~h}$. The reaction mixture was quenched with $1 \mathrm{M} \mathrm{HCl}$ $(10 \mathrm{~mL})$, and extracted several times with ether. The combined extracts were washed with water, dried $\left(\mathrm{MgSO}_{4}\right)$ and concentrated under reduced pressure. The residue was purified by column chromatography $\left(\mathrm{SiO}_{2}\right.$, hexanes-ethyl acetate $\left.=10: 1\right)$ to afford a diastereomeric mixture of diene-iron complexes 20/20'

(304 mg, 100\%) as a yellow solid, which was used in the next step without further characterization.

Decomplexation of 20/20' (200 mg, $0.296 \mathrm{mmol}$ ) with CAN (405 mg, $0.741 \mathrm{mmol}$ ) was carried out in a fashion similar to that for the decomplexation 17/17' except that in DMF (15 mL) was used a solvent instead of methanol. Purification of the residue by column chromatography $\left(\mathrm{SiO}_{2}\right.$, hexanesethyl acetate $=10: 1$ ) followed by a second purification by column chromatography $\left(\mathrm{SiO}_{2}\right.$ impregnated with $\sim 10 \% \mathrm{AgNO}_{3}$, hexanes) gave ( \pm )$8(35 \mathrm{mg}, 40 \%)$ as a colorless oil;

IR (neat) 3054, 2987, 1720, 1422, $1265 \mathrm{~cm}^{-1}$.

${ }^{1} \mathbf{H}$ NMR $\left(\mathrm{CDCl}_{3}\right): \delta=6.73(1 \mathrm{H}, \mathrm{dd}, J=17.3,10.8$ $\mathrm{Hz}, \mathrm{H}-14$ ), 5.34-5.08 (4H total, m, H-3, H-12, H15 and $\left.\mathrm{H}-15_{\mathrm{Z}}\right), 3.63(3 \mathrm{H}, \mathrm{s}, \mathrm{OMe}), 2.77(1 \mathrm{H}, \mathrm{dd}$, $J=14.1,8.3 \mathrm{~Hz}), 2.22-2.16(2 \mathrm{H}, \mathrm{m}), 2.06-1.87(3 \mathrm{H}$, m), $1.83(3 \mathrm{H}, \mathrm{s}, \mathrm{Me}-16), 1.80-1.70(2 \mathrm{H}, \mathrm{m}), 1.58$ $(3 \mathrm{H}$, br s, Me-18), 1.50-1.40 (2H, m), 1.26-0.86 $(3 \mathrm{H}$, m), 0.83 (3H, s, Me-19).

${ }^{13}$ C NMR $\left(\mathrm{CDCl}_{3}\right): \delta=177.3\left(\mathrm{CO}_{2} \mathrm{R}\right), 143.2(\mathrm{C}-4)$, 135.2 (C-14), 133.6, 125.3, 121.5 (C-3), 114.3 (C-15), 55.9, 51.3 (OMe), 48.3, 38.8, 37.9, 37.0, 34.3, 27.5, 20.6, 20.4 (Me-16), 19.4, 18.5, 17.7.

FAB-HRMS $m / z \quad 303.2320$ (calcd for $\mathrm{C}_{20} \mathrm{H}_{31} \mathrm{O}_{2}$ $\left[\mathrm{M}+\mathrm{H}^{+}\right] \mathrm{m} / \mathrm{z}$ 303.2324).

\section{References}

1 - R. Takeda, R. Mori and Y. Hirose, Chem. Lett. 1982, 1625-1628. R. Takeda, H. Naoki,
T. Iwashita, K. Mizukawa, Y. Hirose and M. Inoue, Bull. Chem. Soc. Jpn. 1983, 1125-1132.

2 - J. Li, L. Pan, J. N. Fletcher, W. Lv, Y. Deng, M. A. Vincent, J. P. Slack, T. S. McCluskey, Z. Jia, M. Cushman and A. Douglas Kinghorn, J. Nat. Prod. 2014, 77, 1739-1743.

3 - C. Gaspar-Marques, M. F. Simoes and B. Rodriguez, J. Nat. Prod. 2004, 67, 614-621.

4 - S. Kanokmedhakul, K. Kanokmedhakul and M. Buayairaksa, J. Nat. Prod. 2007, 70, 1122-1126.

5 - For other examples of diterpenes containing a 3-methyl-2Z,4-pentadien-1-yl) side chain see: (a) T. Ohtsuki, T. Koyano, T. Kowithayakorn, N. Yamaguchi and M. Ishibashi, Planta Med. 2004, 70, 1170-1173. (b) C. Gaspar-Marques, M. F. Simoes, A. Duarte and B. Rodriguez, J. Nat. Prod. 2003, 66, 491-496. (c) J. A. Garbarino and A. Molinari, J. Nat. Prod. 1993, 56, 624-626. (d) S. Kanokmedhakul, K. Kanokmedhakul, T. Kanarsa and M. Buayairaksa, J. Nat. Prod. 2005, 68, 183-188. (e) M. S. Hunter, D. G. Corley, C. P. Carron, E. Rowold, B. F. Kilpatrick and R. C. Durley, J. Nat. Prod. 1997, 60, 894-899.

6 - P. Bremond, N. Vanthuyne and G. Audran, Tetrahedron Lett. 2009, 50, 5723-5725.

7 - (a) W. A. Donaldson and S. Chaudhury, Eur. J. Org. Chem. 2009, 3831-3843. (b) W. A. Donaldson, Curr. Org. Chem. 2000, 4, 851-882.

8 - (a) S. Chaudhury, S. Li and W. A. Donaldson, Chem. Commun. 2006, 2069-2070. (b) S.

Chaudhury, S. Li, D. W. Bennett, T. Siddiquee, D. T. Haworth and W. A. Donaldson, Organometallics 2007, 26, 5295-5303.

9 - (a) K. Nabeta, T. Oohata, N. Izumi and K. Katoh, Phytochemistry 1994, 37, 1263-1268. (b) K. Nabeta, T. Ishikawa, T. Kawae and H. Okuyama, J. Chem. Soc., Chem. Commun. 1995, 651-652. (c) K. Nabeta, T. Ishikawa and H. Okuyama, J. Chem. Soc., Perkin Trans. 1 1995, 3111-3115.

10 - D. L. Boger and R. J. Mathvink, J. Org. Chem. 1992, 58, 1429-1443.

11 - P. A. Zoretic, M. Ramchandani and M. L. Caspar, Synth. Commun. 1991, 21, 915-922.

12 - M. Liapis and V. Ragoussis, J. Chem. Soc., Perkin Trans. 1 1985, 815-817.

13 - R. M. Coates and J. E. Shaw, J. Org. Chem. 1970, 35, 2601-2605.

14 - E. Wenkert, A. Afonso, P. Beak, J. W. J. Carney, P. W. Jeffs and J. D. McChesney, J. Org. Chem. 1965, 30, 713-722.

15 - M. Czarny, K. K. Maheshwari, J. A. Nelson and T. A. Spencer, J. Org. Chem. 1975, 40, 2079-2085. (b) E. Wenkert, A. Afonso, J. Bredenberg, C. Kaneko and A. Tahara, J. Am. Chem. Soc. 1964, 86, 2038-2043.

16 - (a) T. Ling, C. Chowdhury, B. Kramer, B. G. Vong, M. Palladino and E. A. Theodorakis, 
J. Org. Chem. 2002, 66, 8843-8853. (b) S. C. Welch, C. P. Hagan, J. H. Kim and P. S. Chu, J. Org. Chem. 1977, 42, 2879-2887. (c) S. C. Welch, C. P. Hagan, W. P. Fleming and J. W. Trotter, J. Am. Chem. Soc. 1977, 99, 549-556.

17 - (a) M. Furlan, M. N. Lopes, J. B. Fernandes and J. R. Pirani, Phytochemistry 1996, 41, 1159-1161. (b) D. Herlem, F. Khuong-Huu and
A. S. Kende, Tetrahedron 1994, 50, 2055-2070.

(c) A. F. Barrero, J. F. Sanchez, J. Altarejos, A. Perales and R. Torres, Phytochemistry, 1992, 31, 615-620. (d) J. Bastard, D. K. Duc, M. Fetizon, M. J. Francis, P. K. Grant, R. T. Weavers, C. Kaneko, G. V. Baddeley, J. M. Bernassau, R. R. Burfitt, P. M. Wuvkulich and E. Wenkert, J. Nat. Prod. 1984, 47, 592-599. 